\title{
PENGARUH MINAT BELAJAR, GAYA BELAJAR, DAN KEMAMPUAN BERPIKIR KREATIF TERHADAP HASIL BELAJAR MATA PELAJARAN DASAR DESAIN GRAFIS
}

\author{
Admaja Dwi Herlambang', Dian Agus Sasmita ${ }^{2}$, dan Satrio Hadi Wijoyo ${ }^{3}$ \\ ${ }^{1}$ Program Studi Pendidikan Teknologi Informasi, \\ Fakultas Ilmu Komputer, Universitas Brawijaya \\ Kota Malang, Indonesia \\ herlambang@ub.ac.id
}

\begin{abstract}
Abstrak
Tujuan penelitian ini untuk mengetahui pengaruh minat belajar, gaya belajar, dan kemampuan berpikir kreatif terhadap hasil belajar siswa di SMK (Sekolah Menengah Kejuruan) jurusan Teknik Komputer dan Jaringan kelas X pada mata pelajaran Dasar Desain Grafis. Penelitian ini menggunakan pendekatan kuantitatif dengan jenis penelitian ex-post facto. Pengambilan data minat belajar dan gaya belajar menggunakan kuesioner dan kemampuan berpikir kreatif menggunakan instrument tes. Data hasil belajar didapatkan dari nilai akhir siswa pada akhir tahun. Sampel berjumlah 50 siswa. Hasil penelitian ini menunjukkan minat belajar, gaya belajar, dan kemampuan berpikir kreatif secara bersama-sama berpengaruh terhadap hasil belajar mata pelajaran Dasar Desain Grafis.
\end{abstract}

Kata kunci: hasil belajar, minat belajar, gaya belajar, kemampuan berpikir kreatif, dasar desain grafis.

\begin{abstract}
The purpose of this study was to determine the effect of interest in learning, learning styles, and the ability to think creatively on the learning outcomes of Vocational High School students at $10^{\text {th }}$ grade of Computer and Network Engineering major in Graphic Design Fundamental subjects. This study uses a quantitative approach with the type of ex-post facto research. Collecting data on interest in learning and learning styles using a questionnaire and the ability to think creatively using tests. The learning outcome data were obtained from the students' final grades at the end of the year. The sample size was 50 students. The results of this study indicate that interest in learning, learning styles, and the ability to think creatively together have effect on learning outcomes in Graphic Design Fundamental subjects.
\end{abstract}

Keywords: learning outcomes, learning interest, learning styles, creative thinking skills, graphic design fundamental 


\section{PENDAHULUAN}

Pembelajaran merupakan proses interaksi antara siswa dan guru pada lingkungan belajar. Pembelajaran terjadi karena adanya tujuan suatu kebutuhan pada diri individu. Pembelajaran dinyatakan berhasil jika mencapai tujuan yang ingin dicapai dengan baik. Perlunya untuk merencanakan pembelajaran untuk mencapai hasil yang diinginkan. Untuk membuat perencanaan pembelajaran yang baik, guru harus mengetahui informasi mengenai karakteristik siswa terlebih dahulu, kemudian guru membuat perencanaan pembelajaran sesuai dengan karakteristik siswa. Menurut Susanto (2016) ada beberapa unsur penting dalam perencanaan pembelajaran, yaitu apa yang diajarkan, bagaimana mengajarkannya, dan bagaimana mengevaluasi hasil belajar siswa. Pembelajaran dilakukan untuk mencapai tujuan pembelajaran yaitu mendapatkan hasil belajar siswa yang memuaskan. Hasil belajar merupakan keahlian yang tumbuh melalui usaha dalam aktivitas belajar untuk mencapai tujuan pembelajaran (Rosyid, et al., 2019). Hasil belajar digunakan untuk menentukan prestasi belajar dengan menggunakan standar pengukuran pengetahuan dan keterampilan. Tingkat kemampuan siswa berbeda diketahui dari hasil belajar mereka yang didapati dari kegiatan evaluasi. Menurut Dalyono (2019) hasil belajar dipengaruhi oleh faktor internal diantaranya adalah Kesehatan artinya apakah siswa saat itu dalam keadaan sehat ketika menerima kegiatan pembelajaran; minat dan motivasi artinya apakah siswa berminat untuk mengikuti kegiatan pembelajaran tersebut; sikap artinya sikap mencerminkan kebiasaan siswa dalam melakukan kegiatan pembelajaran; kebiasaan belajar artinya kebiasaan siswa mengikuti pelajaran dengan baik atau tidak; cara belajar artinya cara siswa dalam memahami materi; inteligensi dan bakat artinya apakah siswa sejak awal memiliki bakat atau kemampuan melebihi siswa lainnya dan faktor eksternal diantaranya adalah keluarga, apakah orang tua memberikan dukungan terhadap siswa; masyarakat, apakah dalam masyarakat siswa merasa terdukung; lingkungan sekitar, apakah lingkungan sekitar baik untuk membuat siswa menjadi lebih baik; sekolah, apakah sekolah menyediakan fasilitas yang dibutuhkan siswa.

Berdasarkan wawancara dengan guru multimedia SMK PGRI 2 Malang diketahui bahwa nilai siswa kurang memuaskan pada mata palajaran Dasar Desain Grafis karena banyak siswa mendapatkan nilai standar. Penyebab kurangnya hasil belajar karena minat belajarnya yang rendah. Minat Belajar adalah kecenderungan akan suatu gairah keinginan yang tinggi yang berfungsi sebagai penggerak yang bagus dalam menggapai prestasi belajar (Furqan, et al., 2016). Definisi operasional minat belajar di dalam penelitian ini adalah tingkat kecenderungan siswa dalam berusaha untuk mencapai penguasaan materi dengan kriteria keberhasilan tertinggi terkait materi mata pelajaran Dasar Desain Grafis. Siswa akan terkesan kurang tertarik untuk belajar lebih giat untuk menambah pengetahuan karena minat belajarnya rendah (Putri \& Isnani, 2015). Guru harus mengembangkan pembelajaran yang menarik agar dapat menumbuhkan perhatian dan minat siswa. Variasi kegiatan pembelajaran dapat menghilangkan rasa bosan siswa. Minat memiliki pengaruh yang besar terhadap tindakan seseorang dengan 
tidak memiliki minat seseorang akan enggan melakukan sesuatu. Sama halnya seperti minat siswa dalam proses pembelajaran. Siswa akan sering mempelajari materi pembelajaran jika materi tersebut menarik bagi siswa begitu juga sebaliknya jika tidak berminat maka akan dikesampingkan. Guru dapat memberikan materi yang memiliki daya tarik bagi siswa agar siswa dapat merasa terdorong untuk mempelajarinya. Ada empat indikator gaya belajar, yaitu: (1) perasaan senang; (3) perasaan tertarik; (3) perhatian; dan (4) kesadaran.

Faktor lain adalah tidak menggunakan cara belajar mereka untuk memperoleh dan mengolah informasi. Cara belajar mereka mengacuh pada gaya belajar yang dapat membantu mereka untuk memahami materi yang akhirnya dapat tersampaikan penjelasan dari guru. Gaya belajar adalah keunikan siswa dalam memperoleh dan mengolah informasi merupakan cara mudah mereka untuk digunakan memahami (Furqan, et al., 2016). Definisi operasional gaya belajar di dalam penelitian ini adalah tingkat kecenderungan siswa dalam memroses dan memahami informasi yang diterima terkait materi mata pelajaran Dasar Desain Grafis. Dengan mengetahui gaya belajar siswa, dapat memberikan informasi ke guru untuk dapat menyampaikan pembelajaran yang tepat. Penerapan pembelajaran sesuai gaya belajar siswa dapat membantu dan memudahkan dalam memahami materi sesuai dengan cara mereka yang akhirnya dapat tersampaikan penjelasan dari guru. Siswa yang memahami gaya belajarnya sendiri akan mengenal diri sendiri dan menerapkan gaya belajarnya untuk lebih mudah memahami pembelajaran di kelas.
Ada dua belas indikator gaya beajar, yaitu (1) kecepatan bicara; (2) gambar; (3) keteraturan; (4) ketidak pedulian pada kebisingan; (5) kejelasan bicara; (6) bersuara; (7) cara mengingat; (8) terganggu kebisingan; (9) aktifitas fisik; (10) kebosanan; (11) gerakan tubuh; dan (12) kerapian.

Keberhasilan hasil belajar siswa yang tinggi juga ditentukan oleh kemampuan berpikirnya. Dengan Dasar Desain Grafis yang merupakan mata pelajaran yang menonjolkan sisi kreativitas, jadi siswa diharuskan untuk bisa berpikir kreatif. Kemampuan berpikir kreatif adalah kemampuan memunculkan ide baru untuk mendapatkan solusi dari suatu permasalahan (Suhadi, et al., 2016). Menurut Wahyuni \& Kurniawan (2018) kemampuan berpikir kreatif merupakan cara berpikir dan merealisasikan imajinasinya dengan memberikan ide-ide baru. Artinya kemampuan berpikir kreatif sebagai sebuah kebiasaan dari pikiran untuk mendapatkan solusi dari permasalahan dengan membuka ide-ide baru. Definisi operasional kemampuan berpikir tingkat tinggi di dalam penelitian ini adalah tingkat kemampuan siswa mengekspresikan solusi yang bermutu atas permasalahan yang disajikan guru pada mata pelajaran Dasar Desain Grafis. Kemampuan berpikir kreatif rendah karena tidak adanya dorongan keingintahuan yang muncul dari diri siswa yang membuat siswa memiliki rasa penasaran terhadap suatu hal. Kemampuan berpikir kreatif dapat dirangsang dengan kebiasaan siswa untuk berpikir kreatif. Kebiasaan tersebut dapat dilakukan saat proses pembelajaran. Indikator berpikir kreatif ada sebelas, yaitu (1) variasi pemanfaatan benda; (2) variasi interpretasi; 
(3) variasi implementasi; (4) variasi ide; (5) variasi cara; (6) variasi arah berpikir; (7) kedalaman pemahaman; (8) pengembangan gagasan; (9) pengujian ide; (10) kepuasan estetika; dan (11) improvisasi.

\section{METODE PENELITIAN}

Penelitian ini berjenis penelitian kuantitatif expost facto. Penelitian kuantitatif lebih memfokuskan gejala faktual yang dikaji secara kuantitatif (Hamdi \& Bahruddin, 2014). Penelitian kuantitatif meggunakan hipotesis sebagai dugaan awal penelitian yang bersifat teoritis. Tujuan penelitian ini untuk mencari pengaruh variabel yang diteliti yang tidak dimanipulasi oleh peneliti untuk mencapai kesimpulan dari hasil penelitian. Anggota populasinya siswa kelas $\mathrm{X}$ dari salah satu Sekolah Menengah Kejuruan (SMK) di Kota Malang (Provinsi Jawa Timur, Indonesia), Jurusan Teknik Komputer dan Jaringan. Penelitian ini menggunakan sampel jenuh, artinya menggunakan seluruh anggota populasi menjadi sampel yang berjumlah 50 siswa. Variabel penelian ini adalah minat belajar $\left(\mathrm{X}_{1}\right)$, gaya belajar $\left(\mathrm{X}_{2}\right)$, kemampuan berpikir kreatif $\left(\mathrm{X}_{3}\right)$, dan hasil belajar (Y). Diagram Penelitian ditunjukkan pada Gambar1.

Data penelitan didapatkan dari penyebaran kuesioner dan asesmen. Instrumen disusun berdasarkan indikator dan kisi-kisi kuesioner yang dijabarkan menjadi beberapa pernyataan dengan skor penilaian menggunakan skala likert pernyataan positif 1-4. Instrumen penelitian divalidasi oleh expert sebelum digunakan sebagai pengambil data. Pengukuran minat belajar dan gaya belajar menggunakan kuesioner, sedangkan kemampuan berpikir kreatif menggunakan asesmen.

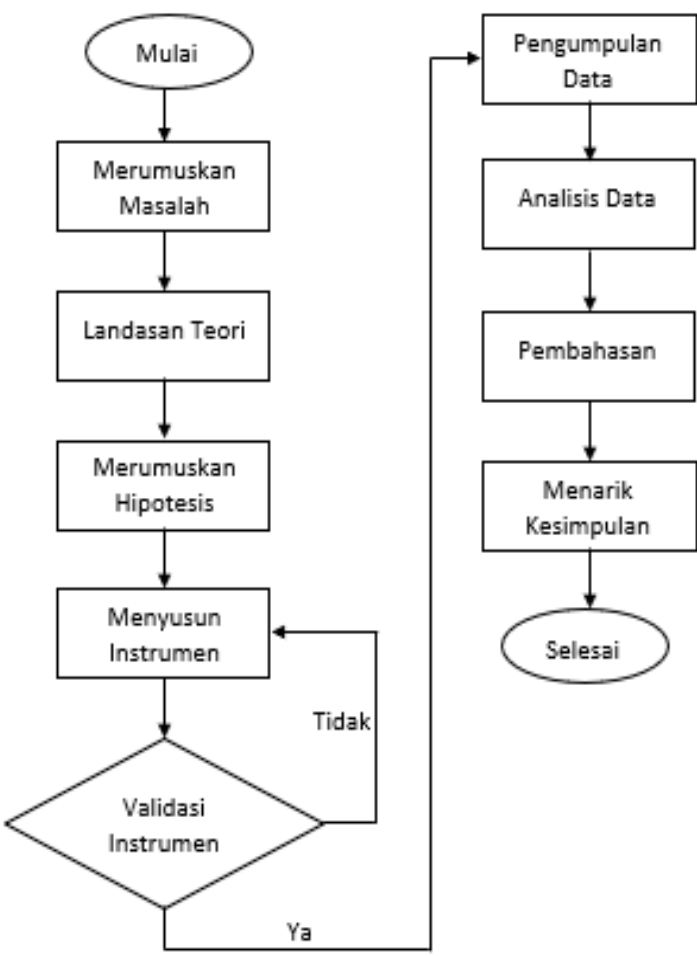

Gambar 1. Diagram Penelitian

Data penelitian dianalisis menggunakan uji asumsi klasik guna melihat nilai residual untuk dapat dilanjutkan ke analisis regresi, dan uji hipotesis yang digunakan untuk menarik kesimpulan akhir penelitian.

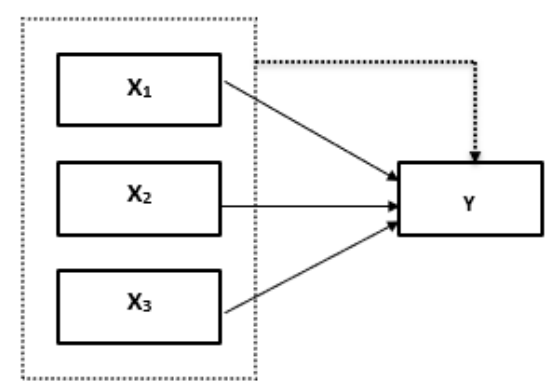

Gambar 2. Paradigma Penelitian

Gambar 2 menunjukkan paradigma penelitian. Ada empat hipotesis yang akan diuji di dalam penelitian ini, yaitu (1) $\mathrm{H}_{0} .1$ : Tidak pengaruh antara minat belajar terhadap hasil belajar siswa pada mata pelajaran Dasar Desain Grafis; (2) $\mathrm{H}_{0} .2$ : Tidak pengaruh antara gaya belajar 
terhadap hasil belajar siswa pada mata pelajaran Dasar Desain Grafis; (3) $\mathrm{H}_{0} .3$ : Tidak pengaruh antara kemampuan berpikir kreatif belajar terhadap hasil belajar siswa pada mata pelajaran Dasar Desain Grafis; dan (4) $\mathrm{H}_{0.4}$ : Tidak ada pengaruh antara minat belajar, gaya belajar, dan kemampuan berpikir kreatif secara bersama-sama terhadap hasil belajar siswa pada mata pelajaran Dasar Desain Grafis. Hasil penelitian akan disimpulkan berdasarkan status keempat $\mathrm{H} 0$ tersebut apakah berhasil ditolak atau gagal ditolak. Apabila H0 berhasil ditolak, maka yang berlaku adalah hipotesis alternatif dari masing-masing $\mathrm{H} 0$. Sebaliknya, apabila H0 gagal ditolak, maka H0 yang akan berlaku secara empirik.

\section{HASIL PENELITIAN DAN PEMBAHASAN}

Uji normalitasi digunakan untuk membuktikan distribusi data apakah berdistribusi normal dengan nilai signifikansi > 0,05. Berdasarkan Tabel 1 didapatkan hasil data berdistribusi nomal karena nilai sig $>0,05$.

Tabel 1. Uji Normalitas

\begin{tabular}{lll}
\hline Relasi & Nilai Sig & Keterangan \\
\hline $\begin{array}{l}\text { Minat Belajar Terhadap } \\
\text { Hasil Belajar }\end{array}$ & 0,200 & Normal \\
$\begin{array}{l}\text { Gaya Belajar terhadap } \\
\text { Hasil Belajar }\end{array}$ & 0,183 & Normal \\
$\begin{array}{l}\text { Kemampuan Berpikir } \\
\text { Kreatif terhadap Hasil }\end{array}$ & 0,200 & Normal \\
Belajar & & \\
\hline
\end{tabular}

Uji linearitas digunakan untuk mencari hubungan antara X dan Y secara signifikansi. Tujuan uji linearitas untuk mencari model regresi yang digunakan merupakan model linear jika nilai deviation from linearity sig > 0,05 artinya memiliki hubungan yang linear.
Tabel 2. Uji Linearitas

\begin{tabular}{lcl}
\hline \multicolumn{1}{c}{ Variabel } & Nilai Sig & Keterangan \\
\hline $\begin{array}{l}\text { Minat Belajar terhadap } \\
\text { Hasil Belajar }\end{array}$ & 0,936 & Linear \\
$\begin{array}{l}\text { Gaya Belajar terhadap } \\
\text { Hasil Belajar }\end{array}$ & 0,122 & Linear \\
$\begin{array}{l}\text { Kemampuan Berpikir } \\
\text { Kreatif terhadap Hasil } \\
\text { Belajar }\end{array}$ & 0,211 & Linear \\
\hline
\end{tabular}

Berdasarkan Tabel 2 didapatkan data bersifat linier karena nilai sig > 0,05. Uji multikolinearitas digunakan untuk mencari hubunagn antar variabel independen yang tidak memiliki korelasi mendekati sempurna dengan menggunakan acuan niali Tolerance > 0,1 dan Variance Inflatio Factor $($ VIF $)<10$ artinya tidak terjadi multikolinearitas.

Berdasarkan Tabel 3 didapatkan nilai toleran minat belajar 0,667 , gaya belajar 0,508, kemampuan berpikir kreatif 0,446 > 0,1 dan nilai VIF minat belajar 1,5 , gaya belajar 1,969, k kemampuan berpikir kreatif $2,147<10$. Dari hasil tersebut maka data tidak terjadi multikolinearitas.

Tabel 1. Uji Multikolinearitas

\begin{tabular}{lcll}
\hline \multicolumn{2}{c}{ Variabel } & \multicolumn{2}{c}{ Nilai } \\
\hline \multicolumn{1}{c}{ Bebas } & Terikat & Toleran & VIF \\
\hline Minat Belajar & Hasil Belajar & 0,667 & 1,5 \\
Gaya Belajar & Hasil Belajar & 0,508 & 1,969 \\
Kemampuan & Hasil Belajar & 0,446 & 2,147 \\
Berpikir Kreatif & & & \\
\hline
\end{tabular}

Uji Heteroskedastisitas digunakan untuk mencari kesamaan varian dan residual dengan melihat nilai sig > 0,05 artinya tidak ada masalah heteroskedastisitas. Berdasarkan Tabel 4 didapatkan nilai signifikansi minat belajar, gaya belajar, dan kemampuan berpikir kreatif secara berurutan 0,386, 0,1970,770 $>0,05$. Dari hasil tersebut maka data tidak ada gejala heteroskedastisitas. 
Tabel 4. Uji Heteroskedastisitas

\begin{tabular}{|c|c|c|}
\hline Variabel & $\begin{array}{c}\text { Nilai } \\
\text { Sig }\end{array}$ & Keterangan \\
\hline Minat Belajar & 0,386 & $\begin{array}{l}\text { Tidak ada Gejala } \\
\text { Heteroskedastisitas }\end{array}$ \\
\hline Gaya Belajar & 0,197 & $\begin{array}{l}\text { Tidak ada Gejala } \\
\text { Heteroskedastisitas }\end{array}$ \\
\hline $\begin{array}{l}\text { Kemampuan } \\
\text { Berpikir Kreatif }\end{array}$ & 0,770 & $\begin{array}{l}\text { Tidak ada Gejala } \\
\text { Heteroskedastisitas }\end{array}$ \\
\hline
\end{tabular}

Berdasarkan tabel 5, didapatkan nilai signifikasi $0,03<0,05$, maka untuk hipotesis pertama $\mathrm{H}_{0} .1$ berhasil ditolak. Artinya, ada pengaruh minat belajar terhadap hasil belajar. R Square bernilai 0,004 , artinya pengaruh yang dimiliki minat belajar sebesar $0,40 \%$ terhadap hasil belajar.

Tabel 5. Hasil Uji Regresi Sederhana Minat Belajar Terhadap Hasil Belajar

\begin{tabular}{lllcc}
\hline \multirow{2}{*}{ Variabel } & \multirow{2}{*}{ Sig } & \multirow{2}{*}{ R Square } & \multicolumn{2}{c}{ Unstandardizad } \\
\cline { 4 - 5 } & & & & $\mathbf{a}$ \\
\hline Minat & & & & \\
Belajar & & & & \\
Terhadap & 0,03 & 0,004 & 72,075 & 0,062 \\
Hasil & & & & \\
Belajar & & & & \\
\hline
\end{tabular}

Untuk unstandardized coefficients dihasilkan nilai constant (a) sebesar 72,075 dan koefisien (b) sebesar 0,062, yang artinya nilai koefisien regresi sebesar 0,062 satuan merupakan nilai penambahan $1 \%$ terhadap nilai hasil belajar. Persamaan regresinya $Y=72,075+0,062 X_{1}$. Koefisien regresi $0,062 \mathrm{X}_{1}$ bernilai positif, artinya minat belajar memiliki arah pengaruh positif.

Berdasarkan tabel 6, didapatkan nilai signifikasi $0,00<0,05$, maka untuk hipotesis kedua $\mathrm{H}_{\mathrm{o}} .2$ berhasil ditolak, artinya ada pengaruh gaya belajar terhadap hasil belajar.
Tabel 6. Hasil Uji Regresi Sederhana Gaya Belajar Terhadap Hasil Belajar

\begin{tabular}{lllll}
\hline \multirow{2}{*}{ Variabel } & \multirow{2}{*}{ Sig } & \multirow{2}{*}{ R Square } & \multicolumn{2}{c}{ Unstandardizad } \\
\cline { 4 - 5 } & & & $\mathbf{a}$ & $\mathbf{b}$ \\
\hline Gaya & & & \\
$\begin{array}{l}\text { Belajar } \\
\text { Terhadap }\end{array}$ & 0,00 & 0,025 & 65,655 & 1,111 \\
$\begin{array}{l}\text { Hasil } \\
\text { Belajar }\end{array}$ & & & & \\
\hline
\end{tabular}

Nilai R Square yang didapatkan adalah sebesar 0,025, yang artinya gaya belajar terhadap hasil belajar memiliki pengaruh sebesar 2,50\%. Untuk nilai constant (a) sebesar 65,655 dan nilai koefisien (b) sebesar 1,111, Koefisien regresi sebesar 1,111 bernilai positif. Jadi didapatkan persamaan regresi $\mathrm{Y}=65,655+1,111 \mathrm{X}_{2}$. Koefisien regresi $1,111 \mathrm{X}_{2}$ bernilai positif, artinya memiliki arah pengaruh yang positif.

Tabel 7. Hasil Uji Regresi Sederhana Kemampuan Berpikir Kreatif Belajar Terhadap Hasil Belajar

\begin{tabular}{lllll}
\hline \multirow{2}{*}{ Variabel } & \multirow{2}{*}{ Sig } & $\begin{array}{l}\mathbf{R} \\
\text { Square }\end{array}$ & \multicolumn{2}{c}{ Unstandardizad } \\
\cline { 4 - 5 } & & & $\mathbf{a}$ & $\mathbf{b}$ \\
\hline $\begin{array}{l}\text { Kemampuan } \\
\text { Berpikir }\end{array}$ & & & & \\
$\begin{array}{l}\text { Kreatif } \\
\text { Terhadap }\end{array}$ & 0,01 & 0,005 & 72,031 & 0,056 \\
Hasil Belajar & & & & \\
\hline
\end{tabular}

Berdasarkan tabel 7, didapatkan nilai signifikasi $0,01<0,05$, maka untuk hipotesis ketiga $\mathrm{H}_{0} .3$ berhasil ditolak, artinya ada pengaruh berpikir kreatif terhadap hasil belajar. Didapatkan nilai $\mathrm{R}$ square sebesar 0,005, yang artinya kemampuan berpikir kreatif berpengaruh $0,50 \%$. Untuk unstandardized coefficients dihasilkan nilai constant (a) sebesar 72,031 dan nilai (b) sebesar 0,056, artinya nilai koefisien regresi sebesar 0,056 satuan merupakan nilai penambahan $1,00 \%$ 
terhadap nilai hasil belajar. Dari nilai constant (a) dan koefisien (b) diperoleh kondisi persamaan regresi $\mathrm{Y}=72,031+0,056 \mathrm{X}_{3}$. Koefisien regresi $0,056 \mathrm{X}_{3}$ bernilai positif, artinya memiliki arah pengaruh yang positif.

Tabel 8. Hasil Uji Regresi Sederhana

Minat Belajar, Gaya Belajar, dan

Kemampuan Berpikir Kreatif Terhadap Hasil Belajar

\begin{tabular}{|c|c|c|c|c|}
\hline \multirow{2}{*}{ Variabel } & \multirow{2}{*}{ Sig } & \multirow{2}{*}{$\begin{array}{l}\text { R } \\
\text { Square }\end{array}$} & \multicolumn{2}{|c|}{ Unstandardizad } \\
\hline & & & $\mathbf{a}$ & $\mathbf{b}$ \\
\hline Minat Belajar & 0,020 & & & 0,001 \\
\hline Gaya Belajar & & 0,028 & 66,213 & 0,193 \\
\hline Kemampuan & & & & \\
\hline $\begin{array}{l}\text { Berpikir } \\
\text { Kreatif }\end{array}$ & & & & 0,067 \\
\hline
\end{tabular}

Berdasarkan Tabel 8, didapatkan nilai signifikasi $0,02<0,05$, maka untuk hipotesis keempat $\mathrm{H}_{0} .4$ berhasil ditolak. Didapatkan nilai $\mathrm{R}$ Square 0,028 , yang artinya memiliki berpengaruh 2,80\% terhadap hasil belajar. Untuk nilai constant (a) sebesar 66,213 dan (b) untuk minat belajar dan gaya belajar sebesar 0,001 dan 0,193 , koefisien regresi sebesar 0,001 dan 0,193 bernilai positif. nilai koefisien (b) untuk kemampuan berpikir kreatif sebesar 0,067 , artinya memiliki arah pengaruh yang positif. Jadi didapatkan persamaan regresi $\mathrm{Y}=66,213+0,001 \mathrm{X}_{1}+0,193 \mathrm{X}_{2}+0,067 \mathrm{X}_{3}$.

Pada pengujian hipotesis untuk hipotesis pertama $\mathrm{H}_{0.1}$ diperoleh nilai sig $0,03<0,05$. Berdasarkan hasil tersebut diambil kesimpulan hipotesis $\mathrm{H}_{0} .1$ berhasil ditolak, artinya minat belajar berpengaruh terhadap hasil belajar. Hasil ini searah dengan penelitian Vani, Paloloang \& Idris (2019) dengan kesimpulan minat belajar berpengaruh secara signifikan. Karena hasil hipotesis ini selaras, maka dapat dikatakan hasil pengujian hipotesis tidak terjadi kesalahan.

Berdasarkan hasil dari uji regresi minat belajar memiliki arah pengaruh positif dengan persamaan regresinya $\mathrm{Y}=$ $72,075+0,062 \mathrm{X}_{1}$. Untuk meningkatkan nilai $Y$ atau hasil belajar maka nilai $\mathrm{X}_{1}$ atau minat belajar perlu ditingkatkan. Pengaruh minat belajar sebesar $0,4 \%$ terhadap hasil belajar, sedangkan 99,6\% dipengaruhi oleh variabel lainnya.

Menurut Vani, Paloloang \& Idris (2019) minat belajar adalah kecenderungan akan rasa ketertarikan seseorang tanpa ada yang menyuruh. Hasil belajar rendah diduga tidak ada ketertarikan siswa untuk meningkatkan hasil belajarnya. Itu membuat siswa merasa kurang bersungguhsungguh dan tidak memperhatikan saat di kelas. Ada juga kemampuan kognitif siswa yang memang tidak cukup tinggi untuk menyimpan semua pelajaran yang diajarkan. Untuk itu guru sebagai pendidik harus memberikan pembelajaran cocok untuk siswa agaar minat belajar siswa dapat muncul. Untuk membuat perencanaan pembelajaran yang baik, guru harus mengetahui informasi mengenai karakteristik siswa terlebih dahulu, kemudian guru membuat perencanaan pembelajaran sesuai dengan karakteristik siswa. Strategi pembelajaran tersebut yang menentukan keberhasilan dalam menarik minat belajar siswa.

Minat dapat membantu proses belajar karena dapat memperkuat ingatan. Minat tidak didapat dimiliki seseorang sejak lahir melainkan dicari. Aspek minat menurut Syahputra (2020) yaitu aspek kognitif yang didasari dengan pengembangan yang berhubungan dengan minat; aspek afektif 
ditampilakn dengan sikap terhadap kegiatan yang diminati; aspek psikomotor lebih mengorientasi proses tingkah laku.

Pada pengujian hipotesis kedua $\mathrm{H}_{0} .2$ diperoleh nilai sig $0,00<0,05$. Dari hasil tersebut diambil kesimpulan hipotesis $\mathrm{H}_{0} .2$ berhasil ditolak, artinya ada pengaruh gaya belajar terhadap hasil belajar. Hasil ini searah dengan penelitian Furqan, Rukun \& Hamid (2016) dengan kesimpulan gaya belajar berpengaruh secara signifikan. Karena hasil hipotesis ini selaras, maka dapat dikatakan hasil pengujian hipotesis tidak terjadi kesalahan.

Berdasarkan hasil dari uji regresi variabel gaya belajar memiliki arah pengaruh positif dengan persamaan regresi $\mathrm{Y}=65,655+1,111 \mathrm{X}_{2}$ Untuk meningkatkan nilai $\mathrm{Y}$ atau hasil belajar maka nilai $\mathrm{X}_{2}$ atau minat belajar perlu ditingkatkan. Pengaruh gaya belajar sebesar $2,5 \%$, sedangkan 97,5\% dipengaruhi oleh variabel lainnya.

Hasil penelitian ini berbeda dengan hasil penelitian dari Wardhani (2016) tentang gaya belajar dimana tidak ada pengaruh pada hasil belajar. Hal ini karena nilai hubungan yang dihasilkan sangat lemah. Penyebabnya pertama, siswa tidak dapat menggunakan gaya belajarnya secara maksimal, dikarenakan siswa tidak mengetahui gaya belajarnya sendiri. Kedua pada aspek guru, strategi pembelajaran guru kurang sesuai kebiasaan siswa siswa.

Menurut penelitian Chania (2016) dengan kesimpulan gaya belajar siswa tidak ada hubungan dengan hasil belajar secara signifikansi. Penyebabnya karena adanya faktor lain seperti bakat, motivasi, sikap siswa. Untuk membuat gaya belajar siswa lebih optimal diperlukan peran guru sebagai pendidik. Guru harus dapat mengenali gaya belajar siswa agar dapat memberikan pembelajaran yang sesuai dengan karakteristik siswa (Suyono, 2018). Guru dapat menggunakan strategi untuk mempermudah siswa dalam proses belajarnya sehingga semua pembelajaran akan dirasa menyenangkan dan mudah. Seperti tidak pembelajaran sampai berjamjam, mengajak siswa untuk mengesprolasi lingkungannya, misal menggunakan objek sebenarnya dalam belajar hal baru.

Setiap individu tentunya ada gaya belajar yang mendominasi (Halman \& Fadhilah, 2017), artinya dari semua jenis gaya belajar setiap individu mempunyai gaya belajar yang mendominasi atau yang paaling efektif dalam menyerap informasi. Menurut Prihatin (2016) gaya belajar merupakan sikap dan perilaku yang disukai peserta didik untuk memahami dalam belajar agar dapat mencapai tujuan. Setiap individu akan menempatan dirinya pada situasi yang baik sesuai dengan gaya belajarnya untuk melakukan pembelajaran yang baik. Untuk itu siswa harus mengetahui gaya belajar mereka sendiri. Gaya belajar merupakan sesuatu yang dapat membantu anda dalam kegiatan belajar. Kebanyakan siswa belajar dengan menggunakan berbagai macam gaya belajar. Tidak ada orang yang tidak memiliki gaya belajar. Jika sudah mengenal gaya belajar tersebut maka akan dengan mudah dapat mengatur dalam menggunakna gaya belajar yang cocok.

Pada pengujian hipotesis ketiga $\mathrm{H}_{0} .3$ diperoleh nilai sig $0,01<0,05$. Berdasarkan hasil tersebut maka disimpulan bahwa hipotesis $\mathrm{H}_{0} .3$ berhasil ditolak, artinya ada pengaruh kemampuan berpikir kreatif terhadap hasil belajar. Hasil ini searah dengan penelitian Maulinda, Waskitoningtyas, \& Khotimah (2018) 
tentang kemampuan berpikir kreatif dengan kesimpulan berpengaruh secara signifikan. Karena hasil hipotesis ini selaras, maka dapat dikatakan hasil pengujian hipotesis tidak terjadi kesalahan secara empirik.

Berdasarkan hasil dari uji regresi kemampuan berpikir kreatif memiliki arah pengaruh positif dengan persamaan regresi $\mathrm{Y}=72,031+0,056 \mathrm{X}_{3}$. Untuk meningkatkan nilai $\mathrm{Y}$ atau hasil belajar maka nilai $\mathrm{X}_{3}$ atau minat belajar perlu ditingkatkan. Pengaruh variabel kemampuan berpikir kreatif sebesar 0,5\% terhadap hasil belajar, sedangkan 99,5\% dipengaruhi oleh variabel lainnya.

Namun penelitian ini tidak selaras dengan penelitian Wahyuni \& Kurniawan (2018) tentang kemampuan berpikir kreatif dengan hasil tidak berpengaruh pada hasil belajar. Penyebabnya pertama pada sisi siswa, siswa kurang terampil dalam berpikir kreatif. Hal ini disebabkan tidak adanya dorongan keingintahuan yang membuat siswa memiliki rasa penasaran terhadap suatu hal (Harisuddin, 2019). Pada aspek guru, hendaknya guru menggunakan metode pembelajaran yang fungsi untuk mengembangkan kreativitas siswa (Agustina \& Noor, 2016). Misalnya menggunakan metode brainstorming dan synectics. Brainstorming artinya mencurahkan gagasan secara spontan sedangkan synectics merupakan pendekatan yang dilakukan dengan penggunaan analogi dalam berpikir kreatif (Maulana, 2017).

Jika ada cara meningkatkan kemampuan berpikir kreatif, ada juga faktor yang menghambat yaitu inkubasi dan faktor sosial (Maulana, 2017). Inkubasi seperti namanya yang artinya berhenti sejenak dan menunda duku kemudian kembali bekerja, sedangkan faktor-faktor sosial yang dapat menghambat kreativitas adalah ketika berkerja ada seseorang yang memperhatikan, pemberian penghargaan atas kreativitas yang dibuat, berjuang untuk memperoleh hadiah, kreativitas yang dibatas oleh seseorang.

Pada pengujian hipotesis keempat $\mathrm{H}_{0} .4$ diperoleh nilai sig 0,02<0,05. Dari hasil tersebut diambil kesimpulan hipotesis $\mathrm{H}_{0} .4$ ditolak, artinya ada pengaruh minat belajar, gaya belajar, dan kemampuan berpikir kreatif terhadap hasil belajar. Hasil ini searah dengan penelitian Furqan, Rukun, \& Hamid (2016) tentang minat belajar dan gaya belajar berpengaruh pada hasil belajar dan penelitian oleh Maulinda, Waskitoningtyas, \& Khotimah (2018) tentang kemampuan berpikir kreatif pada hasil belajar memiliki pengaruh yang kuat. Karena hasil hipotesis ini selaras, maka dapat dikatakan hasil pengujian hipotesis terjadi kesalahan.

Berdasarkan hasil dari uji regresi variabel minat belajar, gaya belajar, dan kemampuan berpikir kreatif memiliki arah pengaruh positif dengan persamaan regresi $Y=66,213+0,001 X_{1}+0,193 X_{2}+0,067 X_{3}$. Untuk meningkatkan nilai $\mathrm{Y}$ atau hasil belajar maka nilai $\mathrm{X}_{1}, \mathrm{X}_{2} \mathrm{X}_{3}$ atau minat belajar perlu ditingkatkan.

\section{KESIMPULAN DAN SARAN}

Berdasarkan hasil analisis dan pembahasan didapatkan empat simpulan. Pertama, minat belajar berpengaruh terhadap hasil belajar siswa kelas X pada mata pelajaran Dasar Desain Grafis. Nilai pengaruh minat belajar sebesar $0,40 \%$ sedangkan 99,6\% lainnya dipengaruhi oleh variabel lain. Kedua, gaya belajar 
berpengaruh terhadap hasil belajar siswa kelas X pada mata pelajaran Dasar Desain Grafis. Nilai pengaruh gaya belajar sebesar $2,5 \%$ sedangkan $97,5 \%$ lainnya dipengaruhi oleh variabel lain.

Ketiga, kemampuan berpikir kreatif berpengaruh terhadap hasil belajar siswa kelas X pada mata pelajaran Dasar Desain Grafis. Nilai pengaruh kemampuan berpikir kreatif sebesar 0,5\% sedangkan 99,5\% lainnya dipengaruhi oleh variabel lain. Keempat, Minat belajar, gaya belajar, dan kemampuan berpikir kreatif berpengaruh terhadap hasil belajar siswa kelas X pada mata pelajaran Dasar Desain Grafis. Nilai pengaruh minat belajar, gaya belajar, dan kemampuan berpikir kreatif sebesar 2,80\% sedangkan 97,20\% lainnya dipengaruhi oleh variabel lain.

Saran yang diberikan, diharapkan untuk siswa mengetahui kemampuannya sendiri dan meningkatkan kemampuannya menjadi lebih baik. Untuk guru diharapkan mengetahui karakteristik siswa sehingga guru dapat menyiapkan strategi pembelajaran yang menarik, kreatif sehingga siswa merasa cocok atau nyaman dan proses pembelajaran dapat tercapai. Saran untuk penelitian selanjutnya, peneliti dapat merubah desain penelian dan menyusuri faktor lainnya yang mempengaruhi hasil belajar, seperti motivasi, intelegensi, fasilitas belajar dan kemampuan berpiki komputasi lainnya.

\section{DAFTAR PUSTAKA}

Agustina, W. \& Noor, F., 2016. Hubungan Hasil Belajar Dan Tingkat Berpikir Kreatif Siswa Dalam Pembelajaran Matematika. Jurnal Pendidikan Matematika, 2(3), pp. 191-200.
Chania, Y., Haviz, M. \& Sasmita, D., 2016. Hubungan Gaya Belajar Terhadap Hasil Belajar Siswa Pada Pembelajaran Biologi Kelas X SMAN 2 SUngai Tarab Kabupaten Tanah Datar. Journal of Sainstek, 8(1), pp. 77-84.

Dalyono, M., 2009. Psikologi Pendidikan. 5 ed. Jakarta: PT RIneka Cipta.

Deporter, B. \& Hernacki, M., 2007. Quantum Learning. 25 penyunt. Bandung: PT Mizan Pustaka.

Furqan, E., Rukun, K. \& Hamid, Y. A., 2016. Kontribusi Minat Belajar dan Gaya Belajar Terhadap Hasil Belajar Melakukan Instalasi Perangkat Jaringan Lokal (LAN) Siswa Kelas 1 TJK SMK Negeri 1 Lhoksukon. Jurnal Vokasional Teknik Elektronika \& Informatika, 4(1), pp. 22-32.

Halman, M. \& Fadhilah, 2017. Pengaruh Gaya Belajar Terhadap Hasil Belajar Fisika Siswa Kelas X TKJ SMK Negeri Limboro. Jurnal Saintifik, 3(2), pp. 136-142.

Hamdi, A. S. \& Bahruddin, E., 2014. Metode Penelitian Kuantitatif Aplikasi Dalam Pendidikan. 1 penyunt. Yogyakarta: CV Budi Utama.

Harisuddin, M. I., 2019. Secuil Esensi Berfikir Kreatif \& Motivasi Belajar Siswa. 1 penyunt. Bandung: PT. Panca Terra Firma.

Maulinda, F., Waskitoningtyas, R. S. \& Khotimah, H., 2018. Pengaruh Kemampuan Berfikir Kreatif dan DIsiplin Belajar Terhadap Hasil Belajar Matematika Siswa Kelas X SMA Negeri Balikpapan Tahun Ajaran 
2017/2018. Jurnal Pendidikan Matematika, 1(2), pp. 114-119.

Prihatin, S. G., 2016. Strategi Belajar. 2 penyunt. Malang: UMMPress.

Putri, D. T. N. \& Isnani, G., 2015. Pengaruh Minat Dan Motivasi Terhadap Hasil Belajar Pada Mata Pelajaran Pengantar Administrasi Perkantoran. Jurnal Pendidikan Bisnis dan Manajemen, 1(2), pp. 118-124.

Rahmat, P. S., 2019. STRATEGI BELAJAR MENGAJAR. Surabaya: Scorpindo Media Pustaka.

Rosyid, M. Z., M. \& Abdullah, A. R., 2019. Prestasi Belajar. 1 penyunt. Malang: Literasi Nusantara.

Suardi, M., 2018. Belajar \& Pembelajaran. 1 penyunt. Yogyakarta: CV Budi Utama.

Sugiono, 2016. Metode Peneltian Kuantitatif, Kualitatif, dan $R \&$ D. 23 penyunt. Bandung: Alfabeta.

Suhadi, S. M. et al., 2016. Implementation of Socratic Method in Online Learning to Enhance Creative Thinking: Analysis Review. Malaysia, s.n.

Susanto, A., 2016. Teori Belajar dan Pembelajaran Di Sekolah Dasar. 4 penyunt. Jakarta: PRENADAMEDIA.
Suyono, A., 2018. Pengaruh Gaya Belajar Terhadap Hasil Belajar Terhadap Mata Pelajaran Akutansi Kelas XI IPS SMAN 3 Tapung Tahun AJaran 2017/2018. JUrnal Pendidikan Ekonomi Akutansi FKIP UIR, 6(1), pp. 1-10.

Syahputra, E., 2020. Snowball Throwing Tingkatkan Minat dan Hasil Belajar. 1 penyunt. Sukabumi: Haura Publising.

Unaradjan, D. D., 2019. Metode Penelitian Kuantitatif. 1 penyunt. Jakarta: Universitas Katolik Indonesia Atma Jaya.

Vani, I. K., Paloloang, B. \& Idris, M., 2019. Pengaruh Persepsi dan Minat Belajar Terhadap Hasil Belajar Matematika Siswa Kelas X SMK Negeri 6 Palu. Jurnal Elektronik Pendidikan Matematika, 6(4), pp. 455-468.

Wahyuni, A. \& Kurniawan, P., 2018. Hubungan Kemampuan Berfikir Kreatif Terhadap hasil Belajar Mahasiswa. Jurnal Matematika, 17(2), pp. 1-8.

Wardhani, S. I., Hanik, U. \& Wulandari, R., 2016. Pengaruh Gaya Belajar Terhadap Hasil Belajar Matematika Mahasiswa Universitas Trunojoyo. Jurnal Pendidikan dan Pembelajaran Matematika (JP2M), 2(1), pp. 42-54. 